\title{
PENDIDIKAN MULTIKULTURAL DI INDONESIA: KONSEPSI FILSAFAT ISLAM
}

\author{
Oleh: St. Zakiah \\ Guru Mi DDI Sepange \\ sittizakiah15@gmail.com
}

\begin{abstract}
Abstrak: Pendidikan Islam tidak membeda-bedakan etnik, ras dan lain sebagainya. Manusia semuanya adalah sama, yang membedakannya adalah ketakwaan mereka kepada Allah SWT. Dalam Islam, pendidikan multikultural mencerminkan bagaimana tingginya penghargaan Islam terhadap ilmu pengetahuan dan tidak ada perbedaan di antara manusia dalam bidang ilmu. Di Indonesia pendidikan multikultural merupakan pendekatan progresif untuk melakukan transformasi pendidikan secara menyeluruh untuk membongkar praktik-praktik diskriminatif dalam proses pendidikan. Pendidikan multikultural didasarkan pada gagasan keadilan sosial dan persamaan hak dalam pendidikan. Tulisan ini mengkritisi James Banks yang menjelaskan bahwa pendidikan multikultural memiliki lima dimensi yang saling berkaitan, namun idelanya dalam pembelajaran hanya membutuhkan penanaman kesadaran kepada siswa yang berdasar pada nilai-nilai kebersamaan dan ke Islaman serta memfasilitasi proses belajar mengajar yang mengubah perspektif monokultural yang esensial, penuh prasangka dan diskriminatif ke perspektif multikulturalis yang menghargai keragaman dan perbedaan, toleran dan sikap terbuka.
\end{abstract}

Key word: Pendidikan, Multikultural dan Islam

\section{PENDAHULUAN}

Sedikitnya selama tiga dasawarsa, kebijakan yang sentralistis dan pengawalan yang ketat terhadap isu perbedaan telah menghilangkan kemampuan masyarakat untuk memikirkan, membicarakan dan memecahkan persoalan yang muncul dari perbedaan secara terbuka, rasional dan damai. Kekerasan antar kelompok yang meledak secara sporadis di akhir tahun 1990-an di berbagai kawasan di Indonesia menunjukkan betapa rentannya rasa 
kebersamaan yang dibangun dalam Negara-Bangsa, betapa kentalnya prasangka antara kelompok dan betapa rendahnya saling pengertian antar kelompok. (Choirul Mahfud, 2009: 17). Konteks global setelah tragedi September 11 dan invasi Amerika Serikat ke Irak serta hiruk pikuk politis identitas di dalam era reformasi menambah kompleknya persoalan keragaman dan antar kelompok di Indonesia.

\section{PEMBAHASAN}

\section{Pendidikan Multikultural}

Pendidikan multikultural di negara-negara yang menganut konsep demokratis seperti Amerika Serikat dan Kanada, bukan hal baru lagi. Mereka telah melaksanakannya khususnya dalam upaya melenyapkan diskriminasi rasial antara orang kulit putih dan kulit hitam, yang bertujuan memajukan dan memelihara integritas nasional. (ScottLash dan Mike Featherstone (ed.). 2002)

Pendidikan multikultural mengakui adanya keragaman etnik dan budaya masyarakat suatu bangsa, sebagaimana dikatakan $R$. Stavenhagen: Keragaman merupakan suatu kondisi pada kehidupan masyarakat. Perbedaan seperti itu ada pada suku bangsa, agama, ras, serta budaya.Keragaman adalah kekayaan dan keindahan suatu bangsa. Pemerintah harus bisa mendorong keberagaman tersebut menjadi suatu kekuatan untuk bisa mewujudkan kebersamaan dalam bermasyarakat serta menjaga nilai-nilai kemanusiaan sehingga tersipta hubungan keselarasan yang lebih baik. (Bhikhu Parekh, Ethnicities 1.1 Journal, (2001): p.109-115).

Di Amerika, sebagai contohnya muncul serangkaian konsep tentang pluralitas yang berbeda-beda, mulai dari melting pot sampai 
multikulturalisme. Sejak Columbus menemukan benua Amerika, berbagai macam bangsa telah menempati benua itu. Penduduk yang sudah berada di sana sebelum bangsa-bangsa Eropa membentuk koloni-koloni mereka di Amerika Utara, terdiri dari berbagai macam suku yang berbeda-beda bahasa dan budayanya. Tetapi di mata bangsa Anglo-Sakson yang menyebarkan koloni di abad ke-17, tanah di Negara baru itu ada kawasan tak bertuan dan bangsa-bangsa yang ditemui di benua baru itu tak lebih dari makhluk primitif yang merupakan bagian dari alam yang mesti ditaklukkan. (Keith Banting and Will Kymlicka, eds. OUP Oxford, 1.2. 2006. P. 112). Dari perspektif kaum Puritan yang menjadi acuan utama sebagian besar pendatang dari Inggris tersebut, berbagai suku bangsa yang dilabel secara generik dengan nama "Indian" adalah bangsa kafir pemuja dewa yang membahayakan kehidupan komunitas berbasis agama tersebut. Di sini terlihat bagaimana pandangan berperspektif tunggal yang datang dari budaya tertentu membutakan mata terhadap kenyataan keragaman yang ada.

Amerika Serikat ketika ingin membentuk masyarakat baru-pasca kemerdekaannya (4 Juli 1776) baru menyadari bahwa masyarakatnya terdiri dari berbagai ras dan asal negara yang berbeda.Oleh karena itu, Bangsa Amerika mencoba mencari terobosan baru yaitu dengan menempuh strategi menjadikan sekolah sebagai pusat sosialisasi dan pembudayaan nilai-nilai baru yang dicita-citakan.Melalui pendekatan inilah, dari SD sampai Perguruan Tinggi. Amerika Serikat berhasil membentuk bangsanya yang dalam perkembangannya melampaui masyarakt induknya yaitu Eropa. (Steven Vertovec and Susanne Wessendorf, eds. Printing; $1^{\text {th }} .2010$. p. 15). 
Kaitannya dengan nilai-nilai kebudayaan yang perlu diwariskan dan dikembangkan melalui sistem pendidikan pada suatu masyarakat, maka Amerika Serikat memakai sistem demokrasi dalam pendidikan yang dipelopori oleh John Dewey. Intinya adalah toleransi tidak hanya diperuntukkan untuk kepentingan bersama akan tetapi juga menghargai kepercayaan dan berinteraksi dengan anggota masyarakat.

Multikulturalisme secara etimologis marak digunakan pada tahun 1950-an di Kanada. Menurut Longer Oxford Dictionary istilah "multiculturalism" merupakan deviasi dari kata "multicultural" Kamus ini menyitir kalimat dari surat kabar Kanada, Montreal Times yang menggambarkan masyarakat Montreal sebagai masyarakat "multicultural dan multi-lingual".( Dalam Shohat, Ella, and Robert Stam, Routledge, 2.2. 2014. p. 8).

Dalam konteks teoritis, belajar dari model-model pendidikan multikultural yang pernah ada dan sedang dikembangkan oleh negara-negara maju, dikenal lima pendekatan, yaitu: pertama, pendidikan mengenai perbedaan-perbedaan kebudayaan atau multikulturalisme. Kedua, pendidikan mengenai perbedaanperbedaan kebudayaan atau pemahaman kebudayaan.Ketiga, pendidikan bagi pluralisme kebudayaan.Keempat pendidikan dwibudaya.kelima, pendidikan multikultural sebagai pengalaman moral manusia. (Azyumardi Azra, 2002).

\section{Multikultural dalam Filsafat Pendidikan Islam}

Dialektika pemikiran filsafat pendidikan Islam di Indonesia pada dasarnya dapat dilihat dari berbagai sudut pandang, yang mana 
masing-masing sudut pandang memiliki tipologi tersendiri. (Abudin Nata, 2005: 19). Pertama, dari sisi sumber pemikiran, selain ia berasal dari ajaran murni agama yang tertuang dalam al-Quran, alSunnah, dan pendapat para ulama, juga dari ideologi berbangsa dan bernegara, sosio-kultural yang berkembang di masyarakat (baik masa lalu maupun masa sekarang), dan tuntutan modernitas yang dihadapi. (Abdul Munir Mulkhan, 2005). Kedua, dari sisi dasar pemikiran, selain menggunakan dasar filsafat Islam, juga memungkinkan penggunaan dasar filsafat Yunani atau filsafat Barat yang pada akhirnya bermuara pada aliran-aliran filsafat pendidikan, seperti Perenialisme, Esensialisme, Eksistensialisme, Progressifisme, dan Rekonstruksionisme. (B. Islam, 1994: 31). Ketiga, dari sisi pendekatan pemikiran, selain menggunakan pendekatan doktriner, normatif, dan idealistik, juga memungkinkan menggunakan pendekatan adopsi, adaptif-akomodatif, atau pragmatis. Keempat, dari sisi pola pemikiran, selain-menampilkan pemikiran yang spekulatif-rasionalistik, juga memungkinkan menampilkan pemikiran yang spekulatif-intuitif. Kelima, dari sisi wilayah jangkauannya, selain pemikiran filsafat yang bersifat universal yang dapat diaplikasikan untuk semua tempat, keadaan, dan zaman, juga memungkinkan bersifat lokal yang khusus untuk tempat, keadaan, dan zaman tertentu saja. Keenamdari sisi wacana pemikirannya yang berkembang, yang menyangkut tinjauan filosofis tentang komponen-komponenpokok aktivitas pendidikan Islam (seperti tujuan, pendidik, peserta didik, kurikulum, metode, dan lingkungan), dan mungkin masih banyak lagi sudut pandang yang lain. (Abuddin Nata and Fauzan, 2005: 44). 
Dalam hubungan ini, dijumpai berbagai pendapat para ahliyang mencoba merumuskan pengertian filsafat pendidikan Islam. Muzayyin Arifin misalnya, mengatakan bahwa filsafat pendidikan Islam pada hakikatnya adalah konsep berpikir tentang kependidikan yang bersumberkan atau berlandaskan ajaran-ajaran agama Islam tentang hakikat kemampuan manusia untuk dapat dibina dan dikembangkan, serta dibimbing menjadi manusia Muslim yang seluruh pribadinya dijiwai oleh ajaran Islam. (Arifin Muzayyin, 2003: 76). Definisi ini memberi kesan bahwa filsafat pendidikan Islam sama dengan filsafat pada umumnya. Dalam arti bahwa filsafat pendidikan Islam mengkaji tentang berbagai masalah yang ada hubungannya dengan pendidikan, seperti manusia sebagai subjek dan objek pendidikan, kurikulum, metode, lingkungan, guru, dan sebagainya. Bedanya dengan filsafat pendidikan pada umumnya bahwa di dalam filsafat pendidikan Islam semua masalah kependidikan tersebut selalu didasarkan kepada ajaran Islam yang bersumberkan al-Qur'an dan al-Hadits. Dengan kata lain bahwa kata Islam yang mengiringi kata filsafat pendidikan itu menjadi sifat, yakni sifat dari filsafat pendidikan tersebut.

Setiap ilmu sudah pasti memiliki fungsi dan kegunaan, termasuk juga filsafat pendidikan. Para ahli di bidang ini telah banyak meneliti secara teoretis mengenai kegunaan filsafat pendidikan. Umar Muhammad al-Taomi al-Syaibani misalnya, mengemukakan tiga manfaat dari mempelajari filsafat pendidikan sebagai berikut:

a. Filsafat pendidikan itu dapat menolong para perancang pendidikan dan orang-orang yang melaksanakannya dalam suatu negara untuk membentuk pemikiran sehat terhadap system pendidikan. Di samping itu, ia dapat menolong tujuan- 
tujuan dan fungsi-fungsinya serta meningkatkan mutu penyelesaian masalah pendidikan, peningkatan, tindakan, dan keputusan termasuk rancangan-rancangan pendidikan mereka. Selain itu, ia juga berguna untuk memperbaiki peningkatan pelaksanaan pendidikan serta kaidah dan cara mereka mengajar yang mencakup penilaian bimbingan dan penyuluhan. (Hamdani Ihsan and Fuad Ihsan, 2007: 27).

b. Filsafat pendidikan dapat menjadi asas yang terbaik untuk penilaian pendidikan dalam arti yang menyeluruh. Penilaian pendidikan itu dianggap persoalan yang perlu bagi setiap pengajaran yang baik. Dalam pengertiannya yang terbaru penilaian pendidikan meliputi segala usaha dan kegiatan yang dilakukan oleh sekolah, institusi-institusi secara umum untuk mendidik angkatan baru dan warga negara dan segala yang berkaitan dengan itu. (Samsul Nizar, 2002: 12).

c. Filsafat pendidikan akan menolong dalam memberikan pendalaman pikiran bagi faktor-faktor spiritual, kebudayaan, sosial, ekonomi, dan politik di Indonesia. Berdasarkan pada kutipan di atas, timbul kesan bahwa kegunaan dan fungsi filsafat pendidikan ternyata amat strategis. la seolah-olah menjadi acuan dalam memecahkan berbagai persoalan dalam pendidikan. (Muljamil Qomar, 2005: 117). Hal ini disebabkan karena yang diselesaikan filsafat pendidikan itu adalah bidang filosofisnya yang menjadi akar dari setiap permasalahan pendidikan. Dengan berpedoman kepada filsafat pendidikan ini, setiap masalah pendidikan dapat dipecahkan secara komprehensif, integrated, dan tidak parsial. 
Di antara idealitas keagamaan Islam sebagaimana tertulis dalam al-Qur'an, adalah untuk saling mengenal dan menghormati berbagai budaya, ras, dan agama sebagai suatu realitas kemanusiaan. Sebagaimana firmal Allah Swt. Dalam QS.al-Hujurat: 13:

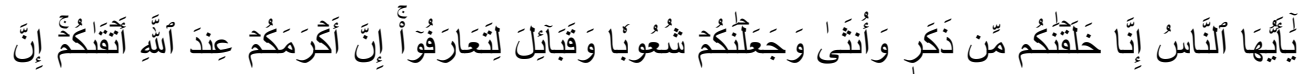

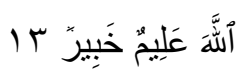

Terjemahnya:

Hai manusia, sesungguhnya Kami menciptakan kamu dari seorang laki-laki dan seorang perempuan dan menjadikan kamu berbangsa-bangsa dan bersuku-suku supaya kamu saling kenal-mengenal.Sesungguhnya orang yang paling mulia diantara kamu disisi Allah ialah orang yang paling takwa diantara kamu. Sesungguhnya Allah Maha Mengetahui lagi Maha Mengenal.

Dalam konteks ini pendidikan multikultural merupakan pendekatan progresif untuk melakukan transformasi pendidikan dan budaya masyarakat secara menyeluruh, sejalan dengan prinsip penyelenggaraan pendidikan yang termaktub dalam UndangUndang Nomor 20/2003 tentang Sistem Pendidikan Nasional pasal 4 ayat 1 yang berbunyi bahwa pendidikan nasional diselenggarakan secara demokratis dan berkeadilan serta tidak diskriminatif dengan menjunjung tinggi hak asasi manusia (HAM), nilai keagamaan, nilai kultural, dan kemajemukan bangsa. (UU RI Nomor 20 Tahun 2003 tentang Sistem Pendidikan Nasional).

\section{Pendidikan multikultural di Indonesia}


Di Indonesia, pendidikan multikultural relatif baru dikenal sebagai suatu pendekatan yang dianggap lebih sesuai bagi masyarakat Indonesia yang heterogen, terlebih pada masa otonomi dan desentralisasi yang baru dilakukan. Pendidikan multikultural yang dikembangkan di Indonesia sejalan pengembangan demokrasi yang dijalankan sebagai counter terhadap kebijakan desentralisasi dan otonomi daerah. Apabila hal itu dilaksanakan dengan tidak berhatihati justru akan menjerumuskan kita ke dalam perpecahan nasional.

Ada beberapa pendekatan dalam proses pendidikan multikultural, yaitu:

Pertama, tidak lagi terbatas pada menyamakan pandangan pendidikan (education) dengan persekolahan (schooling) atan pendidikan multikultural dengan program-program sekolah formal.Pandangan yang lebih luas mengenai pendidikan sebagai transmisi kebudayaan membebaskan pendidik dari asumsi bahwa tanggung jawab primer menegmbangkan kompetensi kebudayaan di kalangan anak didik semata-mata berada di tangan mereka dan justru semakin banyak pihak yang bertanggung jawab karena program-program sekolah seharusnya terkait dengan pembelajaran informal di luar sekolah. (Tatang M Amirin, 2012: 17).

Kedua, menghindari pandangan yang menyamakan kebudayaan kebudayaan dengan kelompok etnik adalah sama. Artinya, tidak perlu lagi mengasosiasikan kebudayaan semata-mata dengan kelompok-kelompok etnik sebagaimana yang terjadi selama ini. Secara tradisional, para pendidik mengasosiasikan kebudayaan hanya dengan kelompok-kelompok sosial yang relatif self sufficient, ketimbang dengan sejumlah orang yang secara terus menerus dan berulang-ulang terlibat satu sama lain dalam satu atau lebih kegiatan. 
Dalam konteks pendidikan multikultural, pendekatan ini diharapkan dapat mengilhami para penyusun program-program pendidikan multikultural untuk melenyapkan kecenderungan memandang anak didik secara stereotip menurut identitas etnik mereka dan akan meningkatkan eksplorasi pemahaman yang lebih besar mengenai kesamaan dan perbedaan di kalangan anak didik dari berbagai kelompok etnik. (Abdullah Aly, makalah pada. Vol. 8. 2005).

Ketiga, karena pengembangan kompetensi dalam suatu "kebudayaan baru" biasanya membutuhkan interaksi inisiatif dengan orang-orang yang sudah memiliki kompetensi, bahkan dapat dilihat lebih jelas bahwa uapaya-upaya untuk mendukung sekolah-sekolah yang terpisah secara etnik adalah antitesis terhadap tujuan pendidikan multikultural. Mempertahankan dan memperluas solidarits kelompok adalah menghambat sosialisasi ke dalam kebudayaan baru.Pendidikan bagi pluralisme budaya dan pendidikan multikultural tidak dapat disamakan secara logis. (Nurul Zuriah, 2011).

Keempat, pendidikan multikultural meningkatkan kompetensi dalam beberapa kebudayaan. Kebudayaan mana yang akan diadopsi ditentukan oleh situasi. (Fakhry, Majid, 2002: 19).

Kelima, kemungkinan pendidikan (baik dalam maupun luar sekolah) meningkatkan kesadaran tentang kompetensi dalam beberapa kebudayaan. Kesadaran seperti ini kemudian akan menjauhkan kita dari konsep dwi budaya atau dikhotomi antara pribumi dan non-pribumi. Dikotomi semacam ini bersifat membatasi individu untuk sepenuhnya mengekspresikan diversitas kebudayaan. Pendekatan ini meningkatkan kesadaran akan multikulturalisme sebagai pengalaman normal manusia. Kesadaran ini mengandung makna bahwa pendidikan multikultural berpotensi untuk menghindari 
dikotomi dan mengembangkan apresiasi yang lebih baik melalui kompetensi kebudayaan yang ada pada diri anak didik. (Malik Fajar, 2004: 54).

Jadi dapat dipahami inti masyarakat adalah kumpulan besar individu yang hidup dan bekerja sama dalam masa relatif lama, sehingga individu-individu dapat memenuhi kebutuhan mereka dan menyerap watak sosial. Kondisi itu selanjutnya membuat sebagian mereka menjadi komunitas terorganisir yang berpikir tentang dirinya dan membedakan ekstensinya dari ekstensi komunitas. Dari sisi lain, apabila kehidupan di dalam masyarakat berarti interaksi antara individu dan lingkungan sosialnya. Maka yang menjadikan pembentukan individu tersebut adalah pendidikan atau dengan istilah lain masyarakat pendidik. (Abdullah Aly, makalah: 2005).

Untuk itu, setiap anggota masyarakat memiliki peranan dan tanggung jawab moral terhadap terlaksananya proses pendidikan. Hal ini disebabkan adanya hubungan timbal balik antara masyarakat dan pendidikan. Dalam upaya memberdayakan masyarakat dalam dunia pendidikan merupakan satu hal penting untuk kemajuan pendidikan.

\section{Kesimpulan dan Implikasi}

Pendidikan multikultural adalah suatu pendekatan progresif untuk melakukan transformasi pendidikan yang secara menyeluruh untuk membongkar kekurangan, kegagalan dan praktik-praktik diskriminatif dalam proses pendidikan. Pendidikan multikultural didasarkan pada gagasan keadilan sosial dan persamaan hak dalam pendidikan. Sedangkan dalam doktrin Islam sebenarnya tidak membeda-bedakan etnik, ras dan lain sebagainya dalam pendidikan. Manusia semuanya adalah sama, yang membedakannya adalah 
ketakwaan mereka kepada Allah SWT. Dalam Islam, pendidikan multikultural mencerminkan bagaimana tingginya penghargaan Islam terhadap ilmu pengetahuan dan tidak ada perbedaan di antara manusia dalam bidang ilmu.

Pendidikan multikultural seyogyanya memfasilitasi proses belajar mengajar yang mengubah perspektif monokultural yang esensial, penuh prasangka dan diskriminatif ke perspektif multikulturalis yang menghargai keragaman dan perbedaan, toleran dan sikap terbuka. Perubahan paradigma semacam ini menuntut transformasi yang tidak terbatas pada dimensi kognitif belaka. Dunia pendidikan tidak boleh terasing dari perbincangan realitas multikultural tersebut. Bila tidak disadari, jangan-jangan dunia pendidikan turut mempunyai andil dalam menciptakan keteganganketegangan sosial. Oleh karena itu, di tengah gegap gempita lagu nyaring "tentang kurikulum berbasis kompetensi", harus menyelinap dalam rasionalitas kita bahwa pendidikan bukan hanya sekedar mengajarkan "ini" dan "itu", tetapi juga mendidik anak kita menjadi manusia berkebudayaan dan berperadaban. Dengan demikian, tidak saatnya lagi pendidikan mengabaikan realitas kebudayaan yang beragam tersebut.

\section{DAFTAR PUSTAKA}

[1] Aly, Abdullah, "Pendidikan multikultural dalam tinjauan pedagogik." Makalah dipresentasikan dalam Seminar Pendidikan Multikultural sebagai Seni Mengelola Keragaman, yang diselenggarakan oleh Pusat Studi Budaya dan 
Perubahan Sosial (PSB-PS) Universitas Muhammadiyah Surakarta, pada. Vol. 8. 2005.

[2] Amirin, Tatang M, "Implementasi pendekatan pendidikan multikultural kontekstual berbasis kearifan lokal di Indonesia." Jurnal pembangunan pendidikan: Fondasi dan aplikasi 1.1 (2012). Diakses tanggal, 22 Juni 2017

[3] Arif, Mahmud, Pendidikan Islam Transformatif. (Cet.l: PT LKiS Pelangi Aksara: Yogyakarta, 2008)

[4] Azra, Azyumardi, "Pendidikan Multikultural: Membangun Kembali Indonesia Bhineka Tunggal Ika." Makalah disampaikan dalam symposium International Antropologi Indonesia ke-3. Denpasar: Kajian Budaya UNUD. 2002. Diakses tanggal, 27 Juni 2017

[4] ---------. Azyumardi. "Esei-esei intelektual Muslim dan pendidikan Islam". (Cet.I: Logos Wacana IImu, Jakarta, 1999).

[5] Baidhawy, Zakiyuddin, "Pendidikan Agama Berwawasan Multikultural". (Cet.II: Erlangga: Jakarta, 2005).

[6] Banting, Keith and Will Kymlicka, eds. "Multiculturalism and the welfare state: Recognition and redistribution in contemporary democracies". OUP Oxford, 1.2. 2006.

[7] Daradjat, Zakiah. "IImu Pendidikan Islam." (Cet.I: Bumi Aksara: Jakarta, 2009)

[8] Fajar, Malik, "Pendidikan Pancasila dan Kewarganegaraan." (Cet. II: Jakarta: Gramedia, 2004)

[9] -------. Malik "Pendidikan Kewarganegaraan Menuju Nation and Character Bulding." Semiloka Nasional tentang 
Revitalisasi Nasionalisme Indonesia Menuju Character and Nation Building (2004). Diakses tanggal 25 Juni 2017

[10] ---------. Malik, "Mendiknas: Kembangkan pendidikan multikulturalisme." Jurnal Pendidikan Indonesia. V.IV, (2004). Diakses tanggal 27 Juni 2017

[11] Fakhry, Majid, R. Mulyadhi Kartenagara, and Nurcholis Madjid. "Sejarah Filsafat Islam". (Cet. I: Pustaka Jaya, 1986)

[12] Hamdani, Ihsan and Fuad Ihsan, "Filsafat Pendidikan Islam." ( Cet. II: Bandung: Pustaka Setia 2001 -2007)

[13] Islam, B.“Ruang Lingkup Filsafat Pendidikan. "Filsafat Pendidikan Islam." (Cet.I: Bumi Aksara Ajakarta, 1994)

[14] Liliweri, Alo."Prasangka \& konflik: komunikasi lintas budaya masyarakat multikultur". PT LKiS Pelangi Aksara, 2005. h

[15] Lash, Scott dan Mike Featherstone (ed.). "Recognition And Difference: Politics, Identity, Multiculture". London: Sage Publication, 2002.

[16] Mahfud, Choirul."Pendidikan Multikultural”. Yogyakarta: Pustaka Pelajar, 2009.

[17] Maslikhah. "Quo Vadis Pendidikan Multikultur Rekontruksi”. "Sistem Pendidikan Berbasis Kebansaan." Surabaya: JP Books (2007).

[18] Mulkhan. Abdul Munir."Kesalehan multikultural: ber-Islam secara autentik-kontekstual di aras peradaban global. Pusat Studi Agama dan Peradaban Muhammadiyah", 2005. Diakses tanggal 28 Juni 2017

[19] Muzayyin. Arifin. "Filsafat Pendidikan Islam." (Cet.l: Jakarta: Bumi Aksara, 2003), 